\title{
Perkembangan S-Select dan C-Select dalam Kalimat Anak Usia 4-9 Tahun
}

\author{
Ahsani Maulidina ${ }^{1}$, Syukur Ghazali ${ }^{1}$, Nurchasanah ${ }^{1}$ \\ ${ }^{1}$ Pendidikan Bahasa Indonesia-Universitas Negeri Malang
}

\begin{tabular}{l} 
INFO ARTIKEL \\
\hline Riwayat Artikel: \\
Diterima: $15-09-2019$ \\
Disetujui: $20-04-2020$ \\
\hline
\end{tabular}

\section{Kata kunci:}

$C$-select; $S$-select development of c-select; development of s-select; child sentences;

children 4-9 yearsold

$S$-select; $C$-select;

perkembangan c-select; perkembangan s-select; kalimat anak; anak usia 4-9 tahun

\begin{abstract}
ABSTRAK
Abstract: The development of a child's sentences is influenced by the development of his age. The development of a child's sentences is seen based on the suitability of the word selection with the meaning between predicate and argumen (s-select) and suitability of the categorial selection with the sentence element function between predicate and argumen (c-select). This study aims to describe the development of sselect and c-select in sentences of children 4-9 years old. This research uses qualitative approach. This research type is cross-sectional. Data in this research are children's sentences containings-select and c-select from children utterances 4-9 years old. There are 3 research result from s-select sentences (1) children aged 4-8 years mastering 11 theta roles and children aged 9 years 13 theta roles, (2) there are 4 kinds of s-select sentences based on the number of the theta roles present, and (3) there are 3 theta roles that can occupy in external arguments, 3 theta roles in internal arguments, 6 theta roles in complement, and 6 theta roles in adjunct. There are 2 research result from c-select sentences (1) child sentences are developed with lexical core V, N, Adj, Num. and Prep and (2) External and internal arguments with categories FN, FN with adjunct, FN coordination, complement with categories FN, FN with adjunct, FN coordination, FA, FV, FNum, and FPrep, and adjunct categorized as FN, FA, and FPrep in sentences with FV predicate, while the other four sentences with FN and FPrep as adjunct.
\end{abstract}

\begin{abstract}
Abstrak: Perkembangan kalimat anak dipengaruhi perkembangan usianya. Perkembangan kalimat anak dilihat dari kesesuaian pemilihan kata dengan makna antara predikat dengan argumennya (s-select) dan kesesuaian pemilihan komponen kategori frasa dengan fungsi unsur kalimat antara predikat dengan argumennya $(c$ select). Penelitian ini bertujuan untuk mendeskripsikan perkembangan s-select dan $c$ select dalam kalimat anak usia 4-9 tahun. Penelitian ini menggunakan pendekatan kualitatif. Jenis penelitian ini adalah cross-sectional research (lintas-seksi). Data penelitian ini adalah kalimat anak yang mengandung s-select dan $c$-select yang bersumber dari tuturan anak usia 4-9 tahun. Hasil penelitian perkembangan kalimat secara $s$-select ada tiga, yaitu (1) anak usia $4-8$ tahun menguasai 11 peran theta dan anak usia 9 tahun 13 peran theta, (2) ada empat macam s-select kalimat berdasarkan jumlah peran theta yang hadir, dan (3) ada tiga peran theta yang dapat menduduki argumen luar, tiga peran theta pada argumen dalam, enam peran theta pada komplemen, dan enam peran theta pada keterangan tambahan. Hasil penelitian perkembangan kalimat secara $c$-select ada dua, yaitu (1) kalimat anak dikembangkan dengan inti leksikal V, N, Adj, Num, dan Prep dan (2) argumen luar dan dalam dengan kategori FN, FN berpenjelas dan FN koordinasi, komplemen dengan kategori FN, FN berpenjelas, FN koordinasi, FV, FA, FNum, dan FPrep, dan keterangan tambahan berkategori FN, FA, dan FPrep pada kalimat berpredikat FV, sedangkan keempat kalimat berpredikat yang lain berkategori FN dan FPrep pada keterangan tambahannya.
\end{abstract}

\author{
Alamat Korespondensi: \\ Ahsani Maulidina \\ Pendidikan Bahasa Indonesia \\ Universitas Negeri Malang \\ Jalan Semarang 5 Malang \\ E-mail: ahsanimaulidina@gmail.com
}

Kalimat anak mempunyai karakteristik yang berbeda dengan kalimat orang dewasa, yaitu luwes, dinamis, dan diatur oleh kaidah tertentu. Karakteristik tersebut menunjukkan bahwa anak berada dalam tahap mengaktifkan kemampuan untuk mempelajari kaidah kalimat yang berlaku di lingkungannya. Proses memahami kaidah kalimat dilakukan secara alami, bertahap, dan tidak diajari. Proses pemerolehan bahasa pada anak terjadi secara alamiah dan tidak disadari (Arsanti, 2014; Hutauruk, 2015). Artinya, anak tidak menyadari bahwa dirinya sedang mengalami pemerolehan bahasa, baik dari proses ataupun hasilnya. 
Kalimat anak berkembang seiring dengan bertambahnya usia. Rakhlin, dkk. (2011) menyatakan bahwa terdapat hubungan atau korelasi antara perkembangan kognitif anak dengan perkembangan sintaksisnya. Kalimat yang strukturnya rumit akan diperoleh akhir daripada kalimat yang strukturnya sederhana. Perkembangan kalimat anak dimulai dari kalimat satu kata kemudian dua kata dan pada akhirnya mengombinasikan dua kata atau lebih untuk membentuk kalimat yang lebih panjang. Taylor \& Taylor (1990) menyatakan bahwa perkembangan kalimat anak dimulai dari kalimat sederhana menuju kalimat yang lebih kompleks. Anak sejak lahir sudah dilengkapi dengan peranti pemerolehan bahasa. Anak usia 4-9 tahun mengalami perkembangan kalimat dengan pesat karena telah memasuki masa usia kritis dan periode sensitif perkembangan bahasa. Masa usia kritis adalah masa anak untuk memperoleh dan mempelajarai bahasa (Dong \& Ren, 2013; Sebayang, 2018). Anak pada usia tersebut dapat memperoleh dan menguasai bahasa yang ada di sekitarnya dalam waktu relatif singkat karena belum memasuki fase lateralisasi bahasa. Anak yang sudah memasuki fase lateralisasi bahasa akan lebih sulit untuk menerima bahasa yang sifatnya baru (Plante, dkk., 2015).

Perkembangan kalimat pada anak lebih mudah diamati karena dari segi sintaktis masih belum stabil atau ajek sehingga memungkinkan untuk terus berkembang, sedangkan kalimat orang dewasa sudah sistematik. Struktur kalimat yang sudah sistematik sudah tidak dapat mengalami perubahan atau tingkat pemerolehan dari segi sintaktisnya berkurang. Selain dari segi sintaksisnya, dari segi semantik orang dewasa sudah mahir untuk mengurai kalimat untuk menentukan makna yang sesuai (Saffran, dkk., 2001).Chomsky (1969) menyatakan bahwa perkembangan pemerolehan tingkat sintaktis akan berkurang seiring dengan bertambahnya usia sehingga tidak dapat dilihat jelas perubahan atau perbedaan kalimat yang dihasilkan orang dewasa. Perkembangan dapat diketahui dengan cara menganalisis kemudian menghubungkan dari sesuatu yang ruang lingkupnya rendah ke jaringan yang lebih luas (Koymen, dkk., 2015). Pada tahap awal perkembangan kalimat, kaidah semantik diperoleh dan berkembang lebih dahulu daripada kaidah sintaksis. Anak tidak melihat kalimat itu benar atau salah, tetapi yang dilihat adalah kalimat tersebut mudah dipahami atau tidak. Saat anak memahami kalimat, struktur, dan kata-kata dari kalimat tersebut cenderung memudar, tetapi maknanya cenderung bertahan dalam pikiran. Setelah memahami kalimat, pengenalan struktur kalimat lebih cepat daripada maknanya yang menandai awal berkembangnya kaidah sintaksis anak.

Perkembangan kalimat anak dapat dilihat dari penguasaan anak terhadap kaidah s-select dan c-select. Kedua kaidah tersebut dapat menentukan kegramatikalan suatu kalimat. Kaidah s-select merupakan kaidah yang mengatur kesesuaian makna antara predikat dengan argumennya. Haegeman (1977) menyatakan bahwa unit-unit semantik menentukan hadirnya suatu argumen untuk menyertai predikat. Penentuan s-select dapat menggunakan teori theta. Satu argumen hanya memiliki satu peran theta yang menonjol atau dominan dan setiap peran theta hanya menduduki satu argumen. Jumlah peran theta yang digunakan atau hadir pada masing-masing bahasa berbeda-beda (Veesar, dkk., 2015). Ada tiga belas peran tematik, yaitu (1) agen/aktor, (2) penderita, (3) tema, (4) pelaksana, (5) penerima, (6) manfaat, (7) tujuan, (8) sumber, (9) lokasi, (10) instrumen, (11) persepsi, (12) waktu, dan (13) cara(Cowper, 1992; Haegeman, 1977).Kaidah c-select merupakan kaidah yang mengatur kesesuaian kategori predikat dengan argumennya. Jenis kategori dari inti leksikal predikat kalimat dapat menentukan jenis kategori dan jumlah argumen yang mengikuti predikat. Sebuah predikat dapat menentukan perlu ada atau tidaknya suatu argumen hadir. Ada tiga jenis argumen yang mendampingi predikat, yaitu argumen luar yang berkedudukan sebagai subjek kalimat, argumen dalam yang berkedudukan sebagai objek kalimat, dan komplemen yang berkedudukan sebagaipelengkap kalimat. Selain argumen, ada konstituen tambahan yang dapat hadir dan bersifat opsional. Konstituen tambahan berupa keterangan tambahan yang berkedudukan sebagai keterangan kalimat. Dalam teori c-select predikat selalu berkategori FV karena yang menjadi subjek penelitian teori tersebut bahasa Inggris, sedangkan dalam bahasa Indonesia FV, FN, FA, FPrep, dan FNum dapat mengisi predikat kalimat. Menurut Samsuri (1985), ada lima jenis frasa yang dapat mengisi predikat, yaitu (1) FN, (2) FA, (3) FV, (4) FPrep, dan (5) FNum. Oleh karena itu, fokus penelitian ini adalah perkembangan s-select dalam kalimat anak usia 4-9 tahun dan perkembangan $c$-select dalam kalimat anak usia 4-9 tahun.

\section{METODE}

Penelitian ini menggunakan pendekatan kualitatif dengan jenis penelitian lintas-seksi atau cross-sectional research. Pendekatan kualitatif dipilih karena (1) penelitian ini bertujuan untuk mendeskripsikan secara nyata perkembangan kalimat anak, (2) jenis data yang digunakan berupa kalimat, dan (3) pengambilan data secara alamiah dari tuturan anak. Alasan dipilihnya penelitian lintas-seksi karena keterbatasan waktu dan pengambilan sumber data dari lima tingkat jenjang usia yang berbeda, yaitu anak usia $4-9$ tahun.

Data dalam penelitian ini adalah kalimatanak yang mengandungs-select dan c-select. Sumber data penelitian ini berupa tuturan anak usia 4-6 tahun di TK Negeri Pembina Purwosari dan 7-9 tahun di SDN Sengon 1. Ada tiga alasan dipilihnya TK dan SD tersebut, yaitu (1) anak-anak di TK dan SD tersebut memiliki organ wicara dan mental yang normal, (2) anakanaknya memiliki kemampuan komunikasi yang baik, dan (3) anak di TK dan SD tersebut aktif dan dapat menerima orang di luar anggota sekolah.

Instrumen utama yang digunakan penelitian ini adalah peneliti. Selain itu, ada dua instrumen pendukung yang digunakan, yaitu instrumen untuk pengumpulan data dan untuk analisis data. Ada tiga instrumen yang digunakan saat pengumpulan data, yaitu pedoman perekaman, pedoman pengamatan dan pencatatan, dan pedoman transkripsi data. Ada empat instrumen yang digunakan dalam analisis data, yaitu dua instrumen pada tahap pra-analisis yang berupa pedoman reduksi dan kodifikasi data dan dua instrumen saat analisis data berupa pedoman analisis s-select dan $c$-select. 
Teknik yang digunakan dalam pengumpulan data ini adalah teknik Simak Libat Cakap (SLC). Ada tiga kegiatan dalam teknik SLC. Pertama, perekaman dilakukan pada dua situasi, yaitu situasi resmi saat anak-anak di dalam kelas dan situasi tidak resmi ketika anak-anak bermain. Kedua, pengamatan dilakukan untuk mengatahui konteks yang dialami dan membantu peneliti mengenali suara dari subjek penelitian. Ketiga, pencatatan dilakukan dengan mencatat tuturan anak usia 4-9 tahun sesuai dengan fokus penelitian.

Analisis data (analisis s-select dan $c$-select) penelitian ini menggunakan teori tata kalimat penguasaan dan ikatan Chomsky yang kemudian dijelaskan lebih lanjut oleh Cowper dan Haegeman. Sebelum analisis, penentuan kalimat dari hasil transkripdilakukan dengan menggunakan kriteria T-unit. Ada tiga langkah analisis data, yaitu reduksi data, analisis $s$-select dan c-select, dan interpretasi data dan penarikan simpulan. Pertama, reduksi data dilakukan dengan cara identifikasi, klasifikasi, dan kodifikasi. Kedua, analisis s-select dilakukan dengan mencari hubungan peran tematik antara predikat dengan argumenargumennya dan analisis c-select dengan cara menentukan kategori frasa pada predikat dan mencari hubungannya dengan kategori frasa pada argumen-argumennya. Ketiga, interpretasi data menggunakan konsep dan kriteria teori perkembangan kalimat. Uji keakuratan dari temuan penelitan dilakukan dengan caraketekunan peneliti dan koreksi silang dengan pakar bahasa dan teman sejawat.

\section{HASIL DAN PEMBAHASAN}

Perkembangan suatu kalimat dapat dilihat dari perkembangan kalimat dari segi semantic dan sintaktisnya. Kalimat yang diproduksi diikat dalam suatu kaidah yang berfungsi untuk mengatur kegramatikalan suatu kalimat, yaitu semantic selection (s-select) dan categorical selection (c-select). Hal tersebut sesuai dengan Schwantes (1991) yang menyatakan bahwa kaidah semantik dan sintaksis lebih diperlukan anak-anak daripada orang dewasa untuk menganalisis sebuah kalimat. Berdasarkan data yang ditemukan pada kalimat anak usia 4-9 tahun dapat dilihat perkembangan kalimatnya dengan menggunakan kaidah s-select dan c-select. Kedua kaidah tersebut dapat melihat kegramatikalan kalimat serta pola perkembangan kalimat yang dihasilkan. Berikut ini paparan dari perkembangan s-select dalam kalimat anak usia 4-9 tahun dan perkembangan $c$-select dalam kalimat anak usia 4-9 tahun.

\section{Perkembangan S-Select dalam Kalimat Anak Usia 4-9 Tahun}

Berdasarkan hasil analisis data, perkembangan s-select dalam kalimat anak usia 4-9 tahun dapat diklasifikasikan menjadi 4, yaitu (1) kalimat berpredikat dengan satu peran theta, (2) kalimat berpredikat dengan dua peran theta, (3) kalimat berpredikat dengan tiga peran theta, dan (4) kalimat berpredikat dengan peran theta opsional. Penggunaan tanda ' $<>$ ' digunakan untuk menunjukkan peran theta argumen dari predikat. Penggunaan cetak miring pada kata dalam tanda ' $<>$ ' menunjukkan peran theta tersebut menduduki argumen luar. Penggunaan cetak biasa pada kata dalam tanda ' $<>$ ' menunjukkan peran theta tersebut ditugaskan langsung oleh $\mathrm{P}$ atau menduduki argumen dalam atau komplemen. Penggunaan tanda [ ] pada kata dalam tanda ' $<$ ' menunjukkan peran theta tersebut menduduki keterangan tambahan. Berikut ini paparan dari keempat klasifikasi tersebut.

Pertama, kalimat berpredikat dengan satu peran theta. Ada tiga jenis peran theta yang hadir pada kalimat berpredikatdengan satu peran theta, yaitu peran agen, tema, dan pelaksana. Ketiga peran theta tersebut menduduki konstituen argumen luar kalimat. Berikut ini paparan dari ketiga peran theta tersebut.

1) Kalimat Berpredikat dengan Peran <Agen>

Anak usia 4-9 tahun sudah menguasai dan menghasilkan kalimat berpredikat satu tempat yang berperan theta agen.

Berikut ini contoh kutipan kalimat berpredikat dengan peran theta agen.

(1) Aku<agen>gak kejar-kejaran. (4K240/A194/BFV)

(2) Aku<agen $>$ mewarnai. (4K245/A198/BFV)

(3) Aku<agen >duduk. (5K283/A153/BFV)

Predikat pada pola ini kejar-kejaran, mewarnai dan duduk berupa kata kerja yang menunjukkan suatu aktivitas yang membutuhkan hadirnya pelaku untuk melakukan kegiatan yang tercermin dalam predikat. Aktivitas pada predikat tersebut hanya dapat dilakukan olehpelaku yang bersifat insani atau bernyawa. Oleh karena itu, argumen luar atau subjek kalimat yang hadir harus berperan theta <agen>. Kata nomina berperan theta agen menggambarkan seseorang yang memiliki kemauan sendiri untuk melakukan tindakan (Cowper, 1992; Haegeman, 1977; Maisarah, dkk., 2016). Menurut Sells (1985), kata pada subjek kalimat lebih sering berperan theta agen daripada tema dan tujuan. Anak usia $4-9$ tahun sering menceritakan suatu kejadian dan aktivitas sehari-hari yang dilakukannya atau dialaminya sehingga dalam kalimatnya anak menggunakan predikat berkategori verba yang menggambarkan aktivitas yang dilakukan atau dialaminya atas dasar keinginannya sendiri.

2) Kalimat Berpredikat dengan Peran <Tema>

Anak usia 4-9 tahun sudah menghasilkan kalimat berpredikat dengan peran theta tema. Predikat kalimat ini hanya menghadirkan satu peran theta tema. Peran tema ini dalam kalimat menduduki posisi argumen luar atau subjek kalimat. Marantz (2013) menyatakan bahwa argumen luar yang berkedudukan sebagai subjek kalimat dapat dianalisis dengan menggunakan teori theta. Kata benda berperan <agen> dan <tema> yang menduduki argumen luar memiliki perbedaan. Kata benda dengan peran 
theta agen harus bersifat insani atau bernyawa, sedangkan peran tema dapat berupa kata benda yang bersifat insani atau non insani. Cowper (1992) menjelaskan bahwa kata benda yang dapat berperan theta tema dapat bersifat insani atau non insani. Hadirnya peran theta agen dan tema dipengaruhi oleh karakteristik predikat. Peran<agen>mengkuti predikat yang menggambarkan suatu aktivitas yang dapat dilakukan oleh seseorang sesuai dengan keinginannya sendiri, sedangkan peran $<$ tema> mengikuti predikat yang menggambarkan suatu kegiatan yang membutuhkan hadirnya sesuatu yang digerakkan dalam predikat. Berikut ini contoh kutipan kalimat berpredikat dengan satu peran 〈tema .

(1) Permennya $\langle$ tema $>$ jatuh. (4K228/A181/BFV)

(2) Sampah $\langle$ tema $\rangle$ itu terbang. (8K6/E1/BFV)

(3) Sepatu $\langle$ tema $\rangle$ ini bisa menyala. (4K227/A180/BFV)

(4) Tepakku<tema $>$ rusak. (8K484/C24/BFA)

Predikat jatuh, terbang, menyala, dan rusak merupakan predikat satu tempat yang menggambarkan suatu aksi. Predikat tersebut membutuhkan sesuatu atau seseorang yang dapat mengalami secara langsung aksi tersebut permen, sampah, sepatu, dan tepakku.

\section{3) Kalimat Berpredikat dengan Peran <Pelaksana>}

Anak usia 4-9 tahun sudah menggunakan dan menguasai pola kalimat berpredikat dengan peran theta pelaksana. Berikut ini contoh kutipan kalimat yang dihasilkan anak usia $4-9$ tahun.

(1) Al <pelaksana>capek. (4K159/A95/BFA)

(2) Aku<pelaksana $>$ keluwen. (4K88/A90/BFV)

(3) Koen<pelaksana>gembengan. (9K203/E242/BFN)

Predikat capek, keluwen, dan gembengan menggambarkan suatu kondisi seseorang. Kondisi tersebut dialami oleh seseorang sehingga ketiga predikat tersebut membutuhkan hadirnya sesuatu yang bersifat insani $A l$, aku, dan koen. Sesuatu yang bersifat insani/orang tersebut berperan theta pelaksana yang menduduki argumen luar atau subjek kalimat. Berdasarkan karakteristik peran <pelaksana> dan <agen> sama-sama menduduki argumen luar dan melekat pada kata berkategori nomina. Perbedaan dari kedua peran theta tersebut adalah jenis predikat kalimatnya. Peran theta agen hadir pada kalimat berpredikat dengan kategori verba, sedangkan pelaksana hadir pada predikat kalimat berkategori nomina, verba, atau adjektiva. Predikat berkategori adjektiva capek, verba keluwen, dan nomina gembengan (penangis) membutuhkan hadirnya pelaku atau seseorang yang bersifat insani $A l$, aku, dan koen. Predikat yang dapat menghadirkan peran <pelaksana> pada argumen luar harus menggambarkan suatu kondisi emosional atau peristiwa yang melibatkan input sensoris, sedangkan predikat yang menghadirkan peran agen menggambarkan suatu aktivitas atau tindakan. Menurut Cowper (1992), peran pelaksana dapat menduduki kata berkategori nomina yang bersifat insani dan dapat melibatkan serta merasakan suatu kondisi atau peristiwa.

Kedua, kalimat berpredikat dengan dua peran theta. Predikat penyusun kalimat pada pola ini merupakan predikat dua tempat. Ada 3 jenis kalimat berpredikat dengan dua peran theta, yaitu (1) peran theta agen pada argumen luar pada kalimat dengan dua peran theta, (2) peran theta tema pada argumen luar pada kalimat dengan dua peran theta, dan (3) peran theta pelaksana pada argumen luar pada kalimat dengan dua peran theta. Dari ketiga jenis tersebut terdapat 6 pola variasi, 3 pola variasi dari jenis pertama, 2 pola variasi dari jenis kedua, dan 1 pola variasi dari jenis ketiga. Anak usia $4-9$ tahun sudah

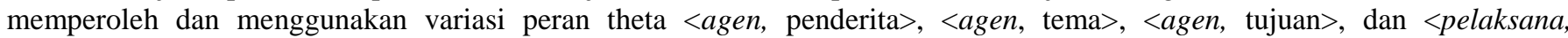
persepsi>. Variasi <tema, penderita> sudah digunakan anak usia 8 tahun dan diperoleh anak usia $8-9$ tahun dan <tema, tujuan> telah digunakan anak usia 5 dan $7-9$ tahun dan diperoleh anak usia $5-9$ tahun. Penguasaan peran theta agen dan pelaksana anak usia 4-9 tahun pada argumen luar terlihat dari sering digunakannya kata benda bersifat insani terutama berupa penggunaan pronomina dan nama. Dardjowidjojo (2000) menyatakan bahwa anak dalam pembuatan kalimat lebih sering menggunakan sudut pandang dirinya sendiri. Sudut pandang tesebut menyebabkan anak sering menuturkan sesuatu yang dialaminya atau dilihatnya sendiri. Pola variasi dari ketiga jenis kalimat berpredikat dengan dua peran theta yang digunakan anak usia 4-9 tahun dapat dilihat pada tabel 1 .

Tabel 1. Pola Variasi Kalimat Berpredikat dengan Dua Peran Theta

\begin{tabular}{llllll}
\hline \multicolumn{6}{c}{ Pola Variasi Kalimat Berpredikat dengan Dua Peran Theta } \\
\hline Usia & \multicolumn{1}{c}{ Agen } & Usia & \multicolumn{1}{c}{ Tema } & Usia & Pelaksana \\
\hline $4-9$ & <agen, penderita> & 8 & <tema, penderita> & $4-9$ & <pelaksana, persepsi> \\
$4-9$ & $\begin{array}{l}\text { <agen, tema> } \\
\text { <agen, tujuan> }\end{array}$ & $5,7-9$ & <tema, tujuan> & & \\
$4-9$ & & & & \\
\hline
\end{tabular}

1) Kalimat Berpredikat dengan Peran <Agen, Penderita $>$

Berikut contoh kutipan kalimat dengan peran <agen, penderita $>$ yang dihasilkan dari tuturan anak usia $4-9$ tahun.

(1) Kenzie <agen >nunjek aku <penderita>. (4K257/A223/BFV)

(2) Jibril <agen >menggebrak meja<penderita>. (7K90/C78/BFV 
Predikat nunjek (meninju) dan menggebrak menggambarkan suatu aktivitas yang hanya dapat dilakukan oleh orang terhadap suatu objek yang dikenai tindakan. Predikat tersebut membutuhkan hadirnya kata berperan <agen>Kenzie dan Jibril sebagai pelaku dan <penderita>aku dan meja sebagai objek yang dikenai tindakan. Kedua kalimat tersebut merupakan kalimat aktif. Jenis kalimat aktif atau pasif tidak memengaruhi peran theta yang mendampingi predikat, tetapi yang membedakan adalah susunan peran thetanya. Berikut bentuk kalimat pasif (1a) dari kalimat (1).

(1a) Aku <penderita>ditunjek Kenzie <agen>.

Berdasarkan kalimat (1a) secara s-select peran theta kalimat aktif dan pasif tidak berbeda walaupun dari segi strukturnya mengalami perubahan. Kenzie berperan theta agen pada kalimat (1) menduduki argumen luar, sedangkan (1a) sebagai komplemen. Aku berperan theta penderita pada kalimat (1) menduduki argumen dalam, sedangkan (1a) sebagai argumen luar. Cowper (1992) menerangkan bahwa pola peran theta kalimat aktif dan pasif sama, tetapi susunannya yang berbeda. Berikut ini polanya.

$$
\text { Kalimat aktif } \quad: \text { Predikat }\left\langle\Theta_{1}, \theta_{2}\right\rangle
$$

Kalimat pasif : Predikat $\left\langle\theta_{2}, \theta_{1}\right\rangle$

2) Kalimat Berpredikat dengan Peran $\langle$ Agen, Tema $>$

Persamaan pola ini dengan pola sebelumnya adalah argumen luar sama-sama berperan 〈agen>, sedangkan perbedaanya pada pola ini peran theta pada argumen dalam/komplemennya berupa peran<tema $>$. Berikut cotoh kutipan kalimatnya.

(1) Aku<agen $>$ mencuci bajunyaadikku<tema $>$. (6K250/B147/BFV)

(2) $\mathrm{Al}<$ agen $>$ sudah menggosok giginya<tema>. (4K128/A65/BFV)

Perbedaan pola pertama dan kedua ini terletak pada predikatnya sehingga peran theta pada argumen dalam/komplemen yang dihasilkan juga berbeda. Haegeman (1977)menyatakan bahawa predikat tidak hanya menentukan jumlah bagian peran yang ditugaskan, jumlah argumen yang terlibat, tetapi juga menentukan peran yang ada pada argumen-argumennya. Peran tema bajunya dan giginya hadir mengikuti predikat yang bersifat bergerak sehingga membutuhkan hubungan dua tempat antara pelaku yang menggerakkan dan sesuatu yang digerakkan. Pelaku yang menggerakkan verba tersebut memainkan peran agen sehingga kategori kata yang menduduki berupa nomina insani aku dan Al. Sesuatu yang digerakkan oleh verba dapat berupa nomina insani atau non insani bajunya dan giginya. Perbedaan dari predikat yang menghadirkan peran theta tema dan penderitapada argumen dalam/komplemen, yakni peran <tema>hadir pada predikat yang menggambarkan suatu aktivitas/tindakan yang tidak dapat mengubah bentuk atau kondisi, sedangkan predikat yang menghadirkan peran <penderita $>$ menggambarkan aktivitas yang dapat mengubah suatu bentuk atau kondisi.

3) Kalimat Berpredikat dengan Peran <Agen, Tujuan>

Kedua pola kalimat sebelumnya, peran penderita dan tema yang mengikuti predikat secara langsung, sedangkan pola ketiga ini diikuti peran tujuan. Peran tujuan itu mengikuti predikat yang menggambarkan suatu arah dari suatu perbuatan itu dilakukan. Berikut ini contoh kutipan kalimat berpredikat <agen, tujuan>.

(1) Aku <agen>mencari tempat duduk<tujuan>. (4K134/A72/BFV)

(2) Aku<agen $>$ pinjam penggaris $<$ tujuan $>$. (7K150/C139/BFV

Verba pada kalimat aktif di atas mencari dan pinjam merupakan verba dua tempat yang membutuhkan argumen dalam dan luar. Penugasan peran theta pada argumen dalam disebut sebagai penugasan langsung dari predikat, sedangkan argumen luar penugasannya ditentukan dari gabungan predikat dengan argumen dalam/komplemen atau keterangan tambahan (Haegeman, 1977). Kedua predikat di atas menggabrakan suatu aktivitas yang berusaha untuk mendapatkan sesuatu. Aktivitas tersebut membutuhkan hadirnya pelaku yang berusaha atau memainkan peran <agen>aku dan sesuatu yang diusahakan atau memainkan peran <tujuan>tempat duduk dan penggaris. Selain dalam bentuk kalimat aktif, anak usia 4-9 tahun juga menggunakan pola peran theta ini dalam kalimat pasif.

\section{4) Kalimat Berpredikat dengan Peran <Tema, Penderita $>$}

Selain peran theta agen, peran theta tema, tujuan, atau penderita juga dapat mengisi argumen luar yang berkedudukan sebagai subjek kalimat. Sells (1985) menyatakan bahwa argumen luar kalimat tidak selalu berperan theta agen,tetapi juga dapat berperan tema/tujuan pada konstruksi pasif. Pola keempat ini dihasilkan anak usia 8 tahun dalam bentuk kalimat pasif dan tidak ditemukan dalam bentuk aktif. Berikut contoh kutipan kalimatnya.

(1) Orang <penderita $>$ pernah digigit anjingnya saudaraku <tema>. (8K333/D101/BFV)

(2) Kakiku $<$ penderita $>$ kenek batu $<$ tema $>$. (8K243/E225/BFV) 
Tidak ada perbedaan peran theta dari kalimat aktif dan pasif. Predikat digigit dan kenek (terkena) menggambarkan suatu aktivitas seseorang (insani) atau sesuatu (non insani) yang menggigit dan mengenai sesuatu (insani/non insani). Seseorang/sesuatu yang menggigit berperan theta tema anjingnya dan batu, sedangkan sesuatu yang digigit dan dikenai berperan theta penderita orang dan kakiku. Orang dan kakiku berperan theta penderita karena dari predikat tersebut dapat mengubah bentuk atau kondisi dari orang dan kaki yang terkena gigit anjing dan terkena batu.

5) Kalimat Berpredikat dengan Peran <Tema, Tujuan>

Pola peran theta <tema, tujuan> tidak banyak digunakan dalam tuturan kalimat anak. Predikat dengan pola ini menggambarkan suatu aktivitas yang bergerak atau ada perubahan tempat sehingga membutuhkan hadirnya sesuatu atau seseorang yang digerakkan dalam predikat yang memainkan peran tema dengan arah dari suatu perbuatan yang memainkan peran tujuan. Berikut contoh kutipan kalimatnya.

(1) Bagas <tema $>$ gak menghadap ke depan <tujuan>. (9K78/E122/BFV)

(2) Febri $\langle$ tema $\rangle$ ini hadap ke belakang $\langle$ tujuan>. (7K87/C77/BFV)

Bagas dan Febri merupakan kata berkategori nomina yang memainkan peran tema, sedangkan ke depan dan ke belakang merupakan kata berkategori frasa preposisi yang memainkan peran tujuan. Cowper (1992) menjelaskan bahwa salah satu ciri dari peran theta tujuan adalah adanya pergerakan arah atau tempat sehingga preposisi ke- dapat menjadi tanda adanya pergerakan.

6) Kalimat Berpredikat dengan Peran <Pelaksana, Persepsi>

Tidak hanya peran theta agen dan tema yang dapat mengisi peran theta pada argumen luar, peran pelaksana juga dapat digunakan. Perbedaan peran theta pelaksana dan agen sudah dijelaskan sebelumnya pada kalimat berpredikat dengan satu peran theta. Persamaan kedua peran theta tersebut adalah hanya sesuatu atau nomina yang bersifat insani yang dapat menerima peran ini. Peran theta persepsi dapat mengikuti predikat yang menggambarkan suatu aktivitas atau kondisi yang melibatkan input sensoris atau emosional. Persepsi ini merupakan peran theta yang hadir mengikuti predikat dua tempat yang salah satu argumen luarnya berperan theta pelaksana. Karakteristik peran theta persepsi adalah sesuatu yang dirasakan atau dialami dari aktivitas sensoris. Berikut contoh kutipan kalimatnya.

(1) Aku <pelaksana $>$ gak krungu ngomongnya<persepsi> Pak Dur. (8K539/C132/BFV)

(2) Aku<pelaksana $>$ gak ingat namanya<persepsi>. (4K137/A73/BFV)

Ketiga, kalimat berpredikat dengan tiga peran theta. Kalimat berpredikat dengan tiga peran theta sudah digunakan dan dikuasai dalam tuturan anak usia 9 tahun, tetapi anak usia $4-8$ tahun belum memperoleh dan menggunakan pola ini. Ada empatvariasi kalimat berpredikat dengan tiga peran theta, yaitu (1) <agen, tema, tujuan>, (2) <agen, tema, lokasi>, (3) <agen, tema, benefaktif>, dan (4) <agen, tema, penerima>. Berikut ini contoh kutipan kalimat dari 4 variasi kalimat berpredikat dengan tiga peran theta.

(1) Saya<agen >masukkan slimenya<tema> ke slorokan<tujuan>. (9K136/E198/BFV)

(2) Kamu <agen >meletakkan slimemu<tema> di sini<lokasi $>$. (9K137/E198/BFV)

(3) Ibuku<agen >nukokno aku<benefaktif $>$ HP Oppo koyok mbakku<tema>. (9K365/D138/BFV)

(4) Aku <agen >membelikan kalung<tema>gawe kucingku<benefaktif $>$. (9K227/B132/BFV)

(5) Aku<agen>ngasih satu bunga<tema> gawe Kak Dina<penerima>. (9K199/D190/BFV)

(6) Aku<penerima $>$ dikasih hadiahpermen<tema $>$ nang Kak Dina<agen>. (9K218/E194/BFV)

Kalimat (1) termasuk contoh kalimat pola pertama. Predikat masukkan (memasukkan) merupakan predikat tiga tempat yang membutuhkan hadirnya seseorang yang melakukan aktivitas memasukkan yang berperan theta agen saya, sesuatu yangdimasukkan yang berperan theta tema slime, dan arah suatu aktivitas memasukkan yang berperan theta tujuanslorokan. Peran theta predikat masukkan/memasukkan<agen, tema, tujuan>. Kalimat (2) merupakan contoh predikat dengan peran theta pola kedua. Perbedaan pola pertama dan kedua ini terletak dari peran theta yang terakhir, yaitu pola pertama berupa peran theta tujuan, sedangkan pola kedua berupa peran theta lokasi. Perbedaan tersebut dilatarbelakangi dari perbedaan makna predikatnya. Predikat kalimat (2) meletakkan menggambarkan suatu aktivitas seseorang yang menaruh sesuatu di suatu tempat. Seseorang yang meletakkan berperan <agen>kamu dan ibuku, sesuatu yang diletakkan berperan theta <tema>slime, dan tempat diletakkanya sesuatu tersebut berperan theta $<$ lokasi $>$ di sini.

Kalimat (3) dan (4) termasuk contoh kalimat dengan pola ketiga. Predikat nukokno/membelikan merupakan aktivitas seseorang membeli sesuatu untuk orang lain. Seseorang yang membeli berperan theta agen $a k u$, sesuatu yang dibeli berperan theta tema HP Oppo dan kalung, dan seseorang atau sesuatu yang dibelikan atau yang mendapat manfaat dari aktivitas membelikan berperan theta benefaktif $a k u$ dan kucingku. Peran theta tema dan benefaktif pada kalimat (3) dan (4) dapat dibolak-balik posisinya. Jika peran theta tema mendahului benefaktif maka kata berperan theta benefaktif harus ditambah preposisi, sedangkan apabila peran theta benefaktif mendahului peran theta tema maka kata berperan theta benefaktif tidak memerlukan preposisi. Perubahan posisi tersebut hanya dapat terjadi jika kata berperan theta benefaktif bersifat insani atau 
berupa nomina persona, sedangkan apabila kedua FN yang berperan theta tema dan benefaktif bersifat non insani maka tidak dapat saling bertukar posisi. Menurut Branigan, dkk. (2008), sifat kebernyawaan dalam kata berpengaruh terhadap struktur sintaktis dan urutan kata. Kalimat (5) dan (6) merupakan contoh dari pola keempat. Kedua kalimat tersebut dari segi hadirnya peran theta memiliki persamaan hanya yang membedakan adalah urutan peran thetanya. Kalimat (5) adalah kalimat aktif, sedangkan kalimat (6) kalimat pasif. Predikat ngasih (memberi) mendeskripsikan suatu aktivitas seseorang untuk memberi sesuatu kepada orang lain. Jadi, pada predikat tersebut ada seseorang yang memberi atau berperan theta agen $a k u$ dan Kak Dina, ada sesuatu yang diberikan yang berperan theta tema bunga dan permen, dan ada seseorang yang menerima hasil pemberian yang berperan theta penerima Kak Dina dan aku. Peran theta penerima hanya dapat mengikuti predikat tertentu, yaitu memberi, menyumbangkan, dan menerima. Cowper (1992) menjelaskan bahwa peran theta penerima ini hadir mengikuti predikat yang menunjukkan perubahan kepemilikan.

Keempat, kalimat berpredikat dengan peran theta opsional. Peran theta opsional ini merupakan konstituen tambahan kalimat yang berkedudukan sebagai keterangan kalimat. Kata berperan theta opsional tidak wajib hadir mendampingi predikat. Keterangan tambahan itu bersifat opsional, seperti keterangan waktu, tempat, dan cara (Haegeman, 1977). Peran theta opsional berfungsi untuk memberi informasi tambahan pada kalimat. Kalimat berpredikat dengan peran theta opsional telah digunakan dalam tuturan anak usia 4-9 tahun. Ada lima pola kalimat berpredikat dengan peran theta opsional, yaitu (1) kalimat berpredikat dengan satu peran theta wajib dan satu peran theta opsional, (2) kalimat berpredikat dengan 2 peran theta wajib dan satu peran theta opsional, (3) kalimat berpredikat satu peran theta wajib dan dua peran theta opsional, (4) kalimat berpredikat dengan tiga peran theta wajib dan satu peran theta opsional, dan (5) kalimat berpredikat dengan dua peran theta wajib dan dua peran theta opsional. Ada enam peran theta yang menduduki keterangan tambahan atau menjadi peran theta opsional dalam kalimat anak usia 4-9 tahun, yaitu <[lokasi] $\rangle,\langle[$ waktu] $\rangle,\langle[$ instrumen] $\rangle,\langle[$ tujuan] $\rangle,\langle[$ cara] $\rangle$, dan $\langle$ [sumber] $\rangle$. Berikut ini contoh kutipan kalimat dengan peran theta opsional.

(1) Aku <agen >jatuh di Semambung <[lokasi]>. (4K185/A137/BFV)

(2) Kelinciku<tema $>$ keluar dari kandang $<$ [sumber] $>$. (9K325/D118/BFV)

(3) Aku <pelaksana $>$ lihat gajah<persepsi $>$ di taman safari<[lokasi]>. (5K102/A1/BFV)

(4) Aku<agen $>$ gambar rumah $<$ tema $>$ karo bulpoin $<$ instrumen] $>$. (7K63/C37/BFV)

(5) Aku<agen>naik mobil<tema $>$ ke Jogja < [tujuan]>. (8K407/D165/BFV)

(6) Dulu< $<$ waktu $]>$ Kak Icha <agen $>$ sekolah di TK Pembina $<[$ lokasi] $>$. (5K219/A109/BFV)

(7) Mamaku<agen>masakno aku<benefaktif > nasi goreng <tema> maeng isuk< $<$ waktu]>. (9K69/E105/BFV)

(8) Kemarin $<$ waktu $]>$ aku<agen $>$ mandiin keoeng <tema $>$ dengan uya $<$ cara $]>$. (8K494/C $31 / \mathrm{BFV})$

Kalimat (1) dan (2) merupakan contoh dari pola pertama. Kedua predikat jatuh dan keluar merupakan predikat satu tempat. Predikat kalimat (1) mendapatkan keterangan tamabahan berupa keterangan tempat di Semambung dan kalimat (2) mendapat keterangan berupa sumber atau asal suatu tindakan/perbuatan terjadi dari kandang. Kalimat (3) - (5) merupakan contoh pola kedua. Predikat kedua kalimat tersebut lihat, gambar, dan naik merupakan predikat dua tempat yang membutuhkan peran agen/pelaksana dan tema. Selain itu, predikat lihat mendapat keterangan tambahan berupa lokasi atau tempat terjadinya suatu aktivitas tersebut di Taman Safari pada kalimat (3), berupa instrumen atau alat yang digunakan untuk melakukan tindakan karo (dengan) bulpoin pada kalimat (4), dan berupa arah suatu tindakan atau ativitas tersebut dituju yang berperan theta tujuan ke Jogja pada kalimat (5). Kalimat (6) adalah contoh dari pola ketiga. Predikat dalam kalimat tersebut merupakan predikat satu tempat yang hanya hadir peran theta agen. Predikat sekolah mendapat dua keterangan tambahan berupa keterangan waktu dulu dan tempat di TK Pembina Purwosari. Kalimat (7) merupakan contoh dari pola keempat dengan predikat tiga tempat. Predikatmasakno (memasakkan) tersebut menghadirkan peran theta agen, tema, dan benefaktif. Selain itu, predikat tersebut dilengkapi dengan informasi tambahan tentang waktu dilakukannya aktivitas tersebut yang berperan theta waktu maeng isuk (tadi pagi). Contoh kalimat dengan pola kelima terdapat pada kalimat (8) Predikat mandiin (memandikan) merupakan predikat dua tempat yang mengahdirkan peran theta agen dan tema. Predikat tersebut mendapat dua keterangan tambahan yang berfungsi untuk memberi informasi tambahan berupa waktu dilakukannya aktivitas tersebut yang berperan theta waktu kemarin dan cara suatu aktivitas tersebut dilakukan yan berperan theta cara dengan uya (garam). Dari keenam peran theta yang berfungsi memberi informasi tambahan atau menduduki keterangan tambahan, peran theta waktu, lokasi, instrumen, tujuan, cara, dan sumber memiliki ciri tersendiri yang dapat dilihat dari preposisi yang digunakan, kecuali peran theta waktu yang tidak menggunakan preposisi. Keterangan tambahan dengan preposisi di- menunjukkan peran theta lokasi. Kata dengan preposisi kepada keterangan tambahan berperan theta tujuan, sedangkan preposisi dari- berperan theta sumber. Preposisi dengan pada kata yang menduduki keterangan tambahan berperan theta cara atau instrumen. Marlina (2012) menyatakan bahwa preposisi to menunjukkan peran tujuan, from untuk peran sumber, dan by atau with menunjukkan peran instrumen.

Jumlah peran theta yang dikuasai anak pada jenjang usia tertentu dan jumlah peran theta yang hadir mendampingi predikat dalam suatu kalimat menunjukkan perkembangan s-select kalimat. Perkembangan s-select kalimat terlihat saat anak berusia 9 tahun. Berdasarkan keempat macam kalimat $s$-select, anak usia $4-8$ tahun sudah menggunakan dan menguasai sebelas peran theta dari ketiga belas peran theta dan anak usia 9 tahun sudah menggunakan dan menguasai ketiga belas peran theta yang disampaikan oleh Cowper dan Haegeman. Sebelas peran theta tersebut terdiri atas peran theta (1) agen, (2) tema, (3) pelaksana, (4) penderita, (5) persepsi, (6) tujuan, (7) waktu, (8) lokasi, (9) sumber, (10) instrumen, dan (11) cara, sedangkan 
peran theta benefaktif dan penerima hanya digunakan dan dikuasai anak usia sembilan tahun. Peran theta benefaktif dan penerima hanya dapat hadir pada predikat tiga tempat, sedangkan anak usia $4-8$ belum menghasilkan kalimat dengan predikat tiga tempat. Peran theta benefaktif dan penerima hadir pada predikat yang menggambarkan suatu aktivitas seseorang yang dilakukan untuk orang lain. Anak usia 4-8 tahun, terutama anak usia taman kanak-kanak (4-6 tahun) masih belum dapat melakukan aktivitas yang menguntungkan atau ditujukan untuk orang lain. Hal tersebut karena anak usia TK (4-6 tahun) tingkat perkembangan kognitifnya masih bersifat egoisentris sehingga tercermin dari aktivitas yang dilakukan dan kalimat yang dihasilkan. Ada tiga peran theta yang dapat menduduki argumen luar, yaitu agen, tema, dan pelaksana. Peran theta yang dapat menduduki argumen dalam adalah peran penderita, tema, dan persepsi, sedangkan pada komplemen dapat berupa peran penderita, tema, persepsi, tujuan, penerima, dan benefaktif. Selain ketiga argumen tersebut, ada enam peran theta yang dapat menduduki keterangan tambahan, yaitu peran lokasi, sumber, instrumen, cara, tujuan, dan waktu.

\section{Perkembangan $\boldsymbol{C}$-Select dalam Kalimat Anak Usia 4-9 Tahun}

Ada lima jenis kalimat $c$-select anak usia 4-9 tahun yang diklasifikasikan berdasarkan kategori frasa yang menduduki suatu predikat kalimat. Pertama, perkembangan kalimat berpredikat FV. Kalimat berpredikat FV diklasifikasikan menjadi dua, yaitu kalimat berpredikat FV berdasarkan kehadiran jumlah argumen dan kalimat berpredikat FV berdasarkan kehadiran jumlah argumen dan keterangan tambahan. Berdasarkan hasil analisis ditemukan 29 variasi pola kalimat berdasarkan kehadiran jumlah argumen dan keterangan tambahan dengan rincian 15 variasi pola kalimat berdasarkan kehadiran argumen dan 14 variasi pola kalimat berdasarkan kehadiran argumen dan keterangan tambahan. Keempat belas variasi pola kalimat berpredikat FV berdasarkan kehadiran jumlah argumen berasal dari tiga pola dasar, yaitu (1) kalimat berpredikat FV dengan satu argumen, (2) kalimat berpredikat FV dengan dua argumen, dan (3) kalimat berpredikat FV dengan tiga argumen. Selain itu, kelima belas variasi pola kalimat FV berdasarkan kehadiran argumen dan keterangan tambahan berasal dari lima pola dasar, yaitu (1) kalimat berpredikat FV dengan satu argumen dan satu keterangan, (2) kalimat berpredikat FV dengan satu argumen dan dua keterangan, (3) kalimat berpredikat FV dengan dua argumen dan satu keterangan, (4) kalimat berpredikat FV dengan dua argumen dan dua keterangan, dan (5) kalimat berpredikat FV dengan tiga argumen dan satu keterangan.

Kedua, perkembangan kalimat berpredikat FN. Kalimat berpredikat FN dikalsifikasikan menjadi dua, yaitu (1) kalimat berpredikat FN berdasarkan kehadiran jumlah argumen dan (2) kalimat berpredikat FN berdasarkan kehadiran jumlah argumen dan keterangan tambahan. Ada satu pola kalimat berpredikat FN berdasarkan kehadiran jumlah argumen, yaitu kalimat berpredikat FN dengan kehadiran satu argumen, sedangkan kalimat berpredikat FN berdasarkan kehadiran jumlah argumen dan keterangan tambahan hanya ada satu pola, yaitu kalimat berpredikat FN dengan kehadiran satu argumen dan satu keterangan tambahan. Variasi paling banyak berjumlah dua variasi pola berasal dari pola kalimat berpredikat FN dengan kehadiran argumen dan keterangan tambahan dan 1 variasi pola dari kalimat berpredikat FN dengan kehadiran satu argumen.

Ketiga, perkembangan kalimat berpredikat FA. Pola kalimat dari kalimat berpredikat FA ini hampir sama dengan kalimat berpredikat FN, yaitu ada dua pola. Dua pola tersebut terdiri atas (1) kalimat berpredikat FA dengan satu argumen dan (1) kalimat berpredikat FA dengan satu argumen dan satu keterangan tambahan. Pola pertama hanya ada satu variasi dan pola kedua ada dua variasi.

Keempat, perkembangan kalimat berpredikat FPrep. Ada dua pola kalimat berpredikat FPrep, yaitu kalimat berpredikat FPrep dengan satu argumen dan kalimat berpredikat FPrep dengan satu argumen dan satu keterangan tambahan. Pola pertama tersebut hanya ada satu variasi dan pola kedua ada dua variasi.

Kelima, perkembangan kalimat berpredikat FNum. Perkembangan kalimat berpredikat FNum hanya memiliki satu pola, kalimat berpredikat FNum dengan satu argumen. Argumen yang hadir adalah argumen luar saja yang berkedudukan sebagai subjek kalimat dengan kategori FN.

Pertama, perkembangan kalimat berpredikat FV. Klasifikasi pertama, kalimat berpredikat FV berdasarkan jumlah argumen. Variasi kalimat berpredikat FV berdasarkan kehadiran jumlah argumen yang digunakan anak-anak dapat dilihat pada tabel 2 .

Tabel 2. Variasi Pola Kalimat Berpredikat FV Berdasarkan Kehadiran Jumlah Argumen

\begin{tabular}{lll}
\hline Satu Argumen & Dua Argumen & Tiga Argumen \\
\hline (FN)-FVIntran tak berpelengkap wajib & (FN)-FVTran-FN & (FN)-FVTran-FN-FN \\
(FN)-FVIntran berpelengkap manasuka & (FN)-FVStran-FN \\
(FN)-FVStran & (FN)-FVIntran-FN \\
& (FN)-FVIntran-FNum \\
& (FN)-FVIntran-FPrep \\
& (FN)-FVIntran-FV \\
& (FN)-FVIntran-FA \\
& (FN)-FVTran/Stran/FVIntran-FNKoordinasi \\
& (FN Kooordinasi)-FVTran/Stran/FVIntran-FN \\
& (FN)-FVTran Koordinasi-FN \\
& (FN+Penjelas(yang+A/V))-FVTran/FVIntran-FNatau (FN)- \\
& FVTran/FVIntran-(FN+Penjelas(yang+A/V)) \\
\hline
\end{tabular}




\section{Kalimat Berpredikat FV dengan Satu Argumen}

Anak usia 4-6 tahun dalam tuturannya hanya menggunakan dua variasi pola kalimat, yaitu (FN)-FVIntran tak berpelengkap wajib dan (FN)-FVStran. Anak usia 7-9 tahun sudah menggunakan tiga variasi pola kalimat, yaitu (FN)FVIntran tak berpelengkap wajib, (FN)-FVIntran berpelengkap manasuka, dan (FN)-FVStran. Variasi pola kalimat berpredikat FV dengan satu argumen (FN)-FVIntran tak berpelengkap wajib dan (FN)-FVStran sudah diperoleh dan dikuasai anak usia 49 tahun, sedangkan (FN)-FVIntran berpelengkap manasuka hanya diperoleh dan dikuasai anak usia $7-9$ tahun. Berikut contoh kalimat berpredikat FV dengan satu argumen yang digunakan anak-anak dalam tuturannya.

(1) Aku lari-lari. (4K157/A90/BFV)

FN FVIntran tak berpelengkap wajib

(2) Al sudah makan. (4K76/A29/BFV)

(3) Tulisanku kecoret. (7K111/C106/BFV)

FN FVIntran berpelengkap manasuka

Kalimat Berpredikat FV dengan Dua Argumen

Variasi pola kalimat berpredikat FV dengan dua argumen yang telah diperoleh dan dikuasai anak usia 4-9 tahun adalah (FN)-FVTran-FN, (FN)-FVStran-FN, (FN)-FVIntran-FN, (FN)-FVIntran-FPrep, (FN)-FVTran/Stran/FVIntran-FN Koordinasi, (FN Koordinasi)-FVTran/Stran/FVIntran-FN, sedangkan variasi pola (FN)-FVIntran-FNum sudah diperoleh anak usia 7-9 tahun. Variasi pola (FN)-FVIntran-FA/FV telah digunakan dalam tuturan anak usia delapan tahun, tetapi frekuensi digunakannya relatif sedikit. Pola (FN)-FVIntran-FV hanya ditemukan satu kali dan sebanyak dua kali untuk (FN)-FVIntranFA. Berikut kutipan kalimat dengan variasi pola (FN)-FVIntran-FA/FV yang digunakan anak usia delapan tahun.

(1) $\frac{\text { Aku gak jadi berenang. }}{\text { FN FVIntran FV }}$ FV $\left.72 / \mathrm{E} 80 / \mathrm{BFV}\right)$

(2) Rasa nanas iku ada manis dan kecut. (8K94/E90/BFV)

$$
\text { FN FVIntran FA }
$$

Pada pola kedua ini kalimat berpredikat FV dengan dua argumen tidak hanya dikembangkan dengan menghadirkan dua argumen saja, melainkan juga mengembangkan dengan menghadirkan frasa koordinasi dan frasa berpenjelas. Frasa yang dikoordinasikan berkategori FN dan FV, sedangkan yang diberi penjelas pada pola ini berkategori FN. FN koordinasi dan FN berpenjelas menduduki konstituen argumen luar dan argumen dalam/komplemen, sedangkan FV koordinasi menduduki predikat. FN dan FV koordinasi dibentuk dengan menambahkan konjungsi dan/sama di antara dua jenis kategori nomina/verba. FN berpenjelas dibentuk dengan menambahkan yang $+A$ atau $y a n g+V$ di belakang FN. Kalimat berpedikat FV dengan argumen luar/dalam/komplemen berkategori FN koordinasi telah digunakan dan diperoleh anak usia $4-9$ tahun. Kalimat berkategori FV koordinasi relatif jarang digunakan anak-anak. Hal tersebut terlihat dari ditemukannya dua kalimat, yaitu satu kalimat dari tuturan anak usia 4 tahun dan satu kalimat dari tuturan anak usia 8 tahun sehingga variasi pola ini belum dikuasai anak usia 4 9 tahun. Kalimat berpredikat FV dengan argumen luar/dalam/komplemen berkategori FN berpenjelas $(y a n g+A / V)$ hanya digunakan dan diperoleh anak usia 8 and 9 tahun. Berikut ini contoh kutipan kalimat berpredikat FV dengan kehadiran FN dan FV koordinasi serta FN berpejelas.

(1) Kak Dina melihat aku yang menari. (8K693/C307/BFV) FN FVTran FN berpenjelas (yang+V)

(2) Anjingnya yang besar itu pernah mengejar ayamku. (8K324/D99/BFV) FN berpenjelas (yang+A) FVTran FN

(3) Kartu seng wes dibeli iki pernah kutahan air minumku. (9K564/C157/BFV) FN berpenjelas (yang+V) FVIntran FN

(4) Aku bawa slime yang banyak. $(9 K 437 / \mathrm{D} 186 / \mathrm{BFV})$

(5) Aku sama Afnan main banyak mainan. (4K89/A37/BFV) FN koordinasi FVIntran FN

(6) Al menggambar rumah dan mobil. (4K96/A43/BFV)

(7) $\frac{\text { Mbakku ngantar sama menjemput aku. }}{\text { FN FV koordinasi }}$ (8K361/D129/BFV)

(8) $\frac{\text { Aku lihat dan nemu apel merah. }}{\mathrm{FN} \text { FV koordinasi }}$ (4K144/A80/BFV)

Pola pertama dan kedua kalimat berpredikat FV menghadirkan jumlah argumen yang berbeda karena jenis frasa verbanya berbeda. Jenis pola pertama FV berupa verba intransitif berpelengkap manasuka dan tak berpelengkap wajib serta verba semitransitif, sedangkan pada pola kedua berupa verba transitif. Menurut Haegeman (1977), jenis kata kerja transitif dan intransitif itu bukan kebetulan, tetapi dilihat dari makna jenis tindakan yang diungkapkan oleh kata kerja tersebut. 


\section{Kalimat Berpredikat FV dengan Tiga Argumen}

Variasi dari pola kalimat ketiga ini (FN)-FVTran-FN-FN hanya digunakan pada anak jenjang usia tertentu. Anak usia 4-8 tahun belum menggunakan variasi ini dalam tuturannya, sedangkan anak usia sembilan tahun sudah menggunakan dan menguasainya. Berikut contoh kutipan kalimat anak usia sembilan tahun dengan variasi pola tersebut.

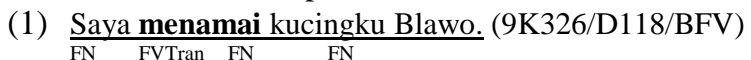

(2) Mama belikan maeman aku. $(9 \mathrm{~K} 368 / \mathrm{A} 211 / \mathrm{BFV})$

Predikat verba transitif pada pola ini menghadirkan tiga argumen, yaitu dua argumen yang mengikuti predikat (argumen dalam dan komplemen) dan satu argumen mendahului predikat (argumen luar). Kalimat berpredikat FV dengan tiga argumen tidak bisa ditambah argumen lagi karena batas maksimal hadirnya argumen berjumlah tiga. Kalimat berpredikat dengan tiga argumen hanya dapat ditambah dengan konstituen tambahan berupa keterangan tambahan. Sells (1985) menyatakan bahwa tiga argumen lebih itu tidak wajar dalam mendampingi suatu predikat. Predikat pada pola ini diikuti langsung oleh dua argumen, yaitu argumen dalam yang berkedudukan sebagai objek dan komplemen yang berkedudukan sebagai pelengkap. Verba transitif pada predikat pola kalimat ini disebut verba dwitransitif karena dapat diikuti dua nomina sekaligus. Verba dwitransitif itu dapat diikuti oleh dua objek, yaitu objek langsung dan objek tidak langsung(Al-Shujairi, dkk., 2015; Samsuri, 1985). Akan tetapi, pada penelitian ini objek tidak langsung disebut sebagai pelengkap. Posisi objek langsung (objek) dan objek tidak langsung (pelengkap) dapat saling bertukar. Al-Shujairi, dkk. (2015) menjelaskan bahwa objek tidak langsung dapat dipindahkan di akhir kalimat dengan menambahkan preposisi.

Klasifikasi kedua, kalimat berpredikat FV berdasarkan kehadiran jumlah argumen dan keterangan tambahan. Variasi kalimat berpredikat FV berdasarkan kehadiran jumlah argumendan keterangan tambahan yang dihasilkan dari tuturan anak usia 4-9 tahun dapat dilihat pada tabel 3.

Tabel 3. Variasi Pola Kalimat Berpredikat FV Berdasarkan Kehadiran Jumlah Argumen dan Keterangan Tambahan

\begin{tabular}{lllll}
\hline Satu Argumen & & Dua Argumen & Tiga Argumen \\
\hline Satu Keterangan & Dua Keterangan & Satu Keterangan & Dua Keterangan & Satu Keterangan \\
\hline (FN)-FVIntran- & (FN)-FVIntran-[FN]- & (FN)-FVTran-FN-[FPrep] & (FN)- & (FN)-FVTran-FN- \\
[FPrep] & [FPrep] & (FN)-FVTran/Stran-FN-[FN] & FVTran/Stran-FN- & FN-[FN] \\
(FN)-FVStran- & (FN)-FVIntran-[FN]- & (FN)-FVTran/Stran-FN-[FA] & [FN]-[FPrep] & \\
[FPrep] & {$[F N]$} & (FN)-FIntran-FN-[FPrep] & \\
(FN)-FVIntran-[FN] & & (FN)-FIntran-FN-[FN] & \\
& & (FN Koordinasi)- & \\
& FVTran/FVStran/FVIntran-FN- & \\
& & [FN/FPrep] & \\
& & (FN)-FVTran/FVStran/FVIntran-FN & & \\
& & Koordinasi-[FN/FPrep] & \\
\hline
\end{tabular}

\section{Kalimat Berpredikat FV dengan Satu Argumen dan Satu Keterangan}

Anak usia 4-9 tahun sudah dapat mengembangkan kalimat berpredikat FV dengan satu argumen dengan menambahkan satu keterangan tambahan. Kategori frasa yang digunakan sebagai keterangan tambahan, yaitu FN dan FPrep. Anak-anak menggunakan keterangan berkategori FN untuk menerangkan waktu, sedangkan FPrep untuk menerangkan tempat/lokasi atau arah. Ketiga variasi pola seperti yang terdapat pada tabel 2, (FN)-FVIntran-[FPrep], (FN)-FVStran-[FPrep], dan (FN)-FVIntran-[FN] sudah digunakan dalam tuturan anak usia $4-9$ tahun. Berikut ini contoh kutipan kalimatnya.
(1) $\frac{\text { Aku kepanasan di sini. }}{\text { FN FVIntran }[\text { [FPrep] }}$ (419/A55/BFV)

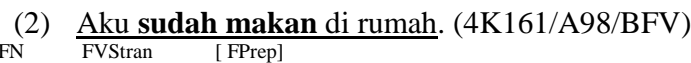
(3) Aku tadi jatuh. (4K217/A176/BFV)

FN [FN] FVIntran

\section{Kalimat Berpredikat FV dengan Satu Argumen dan Dua Keterangan}

Variasi pola kedua ini hampir sama dengan variasi pola pertama, yaitu kalimat berpredikat FV dengan satu argumen, tetapi yang membedakan adalah kehadiran keterangan. Pada variasi pola pertama hanya ada satu keterangan, tetapi pada variasi kedua ini ada dua keterangan. Dua keterangan yang hadir mendampingi predikat berkategori [FN]-[FV] dan [FN]-[FN]. Variasi pola kalimat (FN)-FVIntran-[FN]-[FPrep] ditemukan dalam tuturan anak usia 5 dan 7 tahun, sedangkan variasi pola ini (FN)FVIntran-[FN]-[FN] hanya ditemukan dalam tuturan anak usia 7 tahun. Frekuensi digunakan kedua variasi tersebut relatif sedikit. Hal tersebut dibuktikan hanya ditemukan satu kalimat pada masing-masing variasi pola kalimat. Berikut ini contoh kutipan kalimatnya. 
(1) Sekarang aku duduk di sana. (7K320/C300/BFV)

(2) $\frac{\text { Kemarin arek kelas tiga pulang setelah dhuhur. }}{[\mathrm{FN}]}$ (7K22/E233/BFV)

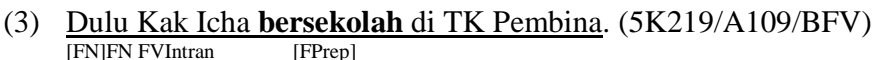

\section{Kalimat Berpredikat FV dengan Dua Argumen dan Satu Keterangan}

Pola ketiga ini paling banyak memiliki variasi pola kalimat dari kalimat berpredikat FV dengan kehadiran argumen dan keterangan tambahan, yaitu sebanyak 7 variasi pola kalimat. Pada pola ini anak-anak tidak hanya mengembangkan kalimat berpredikat FV dengan menambahkan keterangan tambahan saja, melainkan juga sudah membentuk frasa koordinasi, yaitu FN koordinasi pada argumen dalam/komplemen/argumen luar. Pengkoordinasian kategori frasa tersebut dilakukan dengan menambahkan konjungsi dan/sama di antara dua jenis kategori nomina.

Anak usia 4-9 tahun sudah memperoleh dan menguasai variasi pola kalimat berpredikat FVTran dengan kehadiran dua argumen berkategori FN atau FN koordinasi dan keterangan tambahan berkategori FN/FPrep, seperti (FN)-FVTran-FN[FPrep], (FN)-FVTran/Stran-FN-[FN], (FN)-FVTran/FVStran/FVIntran-FN Koordinasi-[FN/FPrep], dan (FN Koordinasi)FVTran/FVStran/FVIntran-FN -[FN/FPrep]. Berbeda dengan variasi dari pola kalimat berpredikat FVIntran, (FN)-FIntran-FN[FPrep] dan (FN)-FIntran-FN-[FN], yang hanya diperoleh oleh anak usia $6-9$ tahun, sedangkan anak usia $4-5$ tahun hanya menggunakan saja belum sampai tahap memperoleh. Variasi pola kalimat berpredikat FV dengan dua argumen berkategori FN dan keterangan berkategori FA ini hanya ditemukan satu kalimat pada tuturan anak usia delapan tahun, (FN)-FVTran/Stran-FN[FA]. Kalimat dengan keterangan tambahan FA tersebut belum dikuasai anak usia $4-9$ tahun. Berikut ini contoh kutipan kalimatnya.

(1) Sampean sama aku gak mau beli itu nang kono. (4K120/A56/BFV) FN FVTran FN [FPrep] (2) Itu tadi minta jajane sama permene Qian. (5K260/A138/BFV)

(3) Altadi nyari tasnya. (4K132/A71/BFV)

(4) $\frac{\text { Aku tahu warna apel di buku. }}{\text { FN FVTran FN [FPrep] }}$ (4K143/A80/BFV)

(5) Tadi aku ketemu bu guru. $(6 \mathrm{~K} 118 / \mathrm{B} 71 / \mathrm{BFV})$

(6) Aku punya puzzle di rumah. $(6 \mathrm{~K} 116 / \mathrm{B} 68 / \mathrm{BFV})$ FN FVIntran FN [FPrep]

(7) Arek-arek iku buang sampah karo ngamuk. (8K534/C119/BFV) FN FVTran FN [FA]

\section{Kalimat Berpredikat FV dengan Dua Argumen dan Dua Keterangan}

Pola ini hanya memiliki satu variasi, yaitu (FN)-FVTran/Stran-FN-[FN]-[FPrep]. Variasi tersebut ditemukan dalam kalimat yang dituturkan anak usia delapan tahun. Variasi ini sudah diperoleh anak usia delapan tahun, tetapi masih belum dikuasai karena kalimat yang dihsailkan relatif terbatas. Oleh karena itu anak usia 4-7 tahun belum memperoleh dan menguasai variasi pola kalimat ini. Berikut contoh kutipan kalimat dengan variasi ini.

(1) Aku wingi maem ayam krispi ndek Miami. (8K642/C227/BFV) FN [FN] FVStran FN [FPrep]

\section{Kalimat Berpredikat FV dengan Tiga Argumen dan Satu Keterangan}

Pola kalimat ini hanya memiliki satu variasi pola kalimat yang dihasilkan dari tuturan anak usia sembilan tahun, (FN)FVTran-FN-FN-[FN]. Hanya ada satu kalimat anak usia 9 tahun yang menggunakan variasi pola kalimat ini. Variasi pola kalimat ini belum dikuasai anak usia 4-9 tahun, tetapi sudah digunakan dalam tuturan anak usia sembilan tahun, meskipun relatif sedikit. Berikut contoh kutpan kalimatnya.

(1) Mamaku masakno aku nasi goreng maeng isuk. (9K69/E105/BFV)

$$
\text { FN FVTran FN FN }[\mathrm{FN}]
$$

Kedua, perkembangan kalimat berpredikat FN. Variasi pola kalimat berpredikat FN yang dihasilkan dari tuturan anak usia 4-9 tahun dapat dilihat pada tabel 4. 
Tabel 4. Variasi Pola Kalimat Berpredikat FN

\begin{tabular}{|c|c|c|c|c|c|c|c|}
\hline \multicolumn{4}{|c|}{$\begin{array}{c}\text { Variasi Kalimat Berpredikat FN } \\
\text { Berdasarkan Kehadiran Jumlah Argumen }\end{array}$} & \multicolumn{4}{|c|}{$\begin{array}{c}\text { Variasi Kalimat Berpredikat FN Berdasarkan Kehadiran Jumlah Argumen } \\
\text { dan Keterangan Tambahan }\end{array}$} \\
\hline \multicolumn{4}{|c|}{ Satu Argumen } & \multicolumn{4}{|c|}{ Satu Argumen dan Satu Keterangan } \\
\hline 4 & $(\mathrm{FN})-\mathbf{F N}$ & 7 & $(\mathrm{FN})-\mathbf{F N}$ & 4 & - & 7 & - \\
\hline 5 & $(\mathrm{FN})-\mathbf{F N}$ & 8 & $(\mathrm{FN})-\mathbf{F N}$ & 5 & - & 8 & $(\mathrm{FN})-\mathrm{FN}-[\mathrm{FN}]$ \\
\hline 6 & $(\mathrm{FN})-\mathbf{F N}$ & 9 & $(\mathrm{FN})-\mathbf{F N}$ & 6 & - & 9 & $\begin{array}{l}\text { (FN)-FN-[FPrep] } \\
\text { (FN)-FN-[FN] } \\
\text { (FN)-FN-[FPrep] }\end{array}$ \\
\hline
\end{tabular}

Pola kalimat berpredikat FN dengan satu argumen hanya ada satu variasi dan sudah diperoleh dan dikuasai anak usia 4-9 tahun. Variasi pola kalimat ini hanya menghadirkan argumen luar berkategori FN untuk mendampingi predikat berkategori FN, (FN)-FN. Berikut ini contoh kutipan kalimat dengan variasi pola ini.

(1) Itu bukan gambar hiu. (4K204/A157/BFN)

FN FN

Pola kalimat berpredikat FN dengan kehadiran satu argumen dan satu keterangan tambahan. Pola ini hanya memiliki dua variasi, yaitu (FN)-FN-[FN] dan (FN)-FN-[FPrep]. Kedua variasi tersebut kategori frasa yang mengisi argumen luarnya sama, tetapi kategori frasa keterangan tambahannya yang berbeda, yaitu FN dan FPrep. Variasi (FN)-FN-[FPrep] dan (FN)-FN[FN] telah digunakan dalam tuturan anak usia 8 dan 9 tahun. Kedua variasi tersebut frekuensi digunakannya sangat sedikit sehingga dapat dikatakan belum dikuasai. Berikut contoh kutipan kalimatnya.

(1) Di hutan temannya monyet iku gorilla. (8K12/E17/BFN)

(2) Saya besok bayarnya. (8K193/E169/BFN) FN [FN] FN

Ketiga, perkembangan kalimat berpredikat FA. Berikut ini tabel 5 variasi kalimat dari kedua pola tersebut yang digunakan anak usia $4-9$ tahun.

Tabel 5. Variasi Pola Kalimat Berpredikat FA

\begin{tabular}{|c|c|c|c|c|c|c|c|}
\hline \multicolumn{4}{|c|}{$\begin{array}{c}\text { Variasi Kalimat Berpredikat FA Berdasarkan } \\
\text { Kehadiran Jumlah Argumen }\end{array}$} & \multicolumn{4}{|c|}{$\begin{array}{c}\text { Variasi Kalimat Berpredikat FA dengan } \\
\text { Keterangan Tambahan }\end{array}$} \\
\hline Usia & $\begin{array}{l}\text { Satu } \\
\text { Argumen }\end{array}$ & Usia & Satu Argumen & Usia & $\begin{array}{l}\text { Satu Argumen dan } \\
\text { Satu Keterangan }\end{array}$ & Usia & $\begin{array}{l}\text { Satu Argumen dan } \\
\text { Satu Keterangan }\end{array}$ \\
\hline 4 & (FN)-FA & 7 & $(\mathrm{FN})-\mathbf{F A}$ & 4 & - & 7 & (FN)-FA-[FN] \\
\hline 5 & $(\mathrm{FN})-\mathbf{F A}$ & 8 & $(\mathrm{FN})-\mathbf{F A}$ & 5 & (FN)-FA-[FPrep] & 8 & (FN)-FA-[FPrep] \\
\hline 6 & $(\mathrm{FN})-\mathbf{F A}$ & 9 & $\begin{array}{l}\text { FN)-FA Koordinasi } \\
\text { (FN)-FA } \\
\text { (FN)-FA Koordinasi }\end{array}$ & 6 & $\begin{array}{l}\text { (FN)-FA- }[\mathrm{FN}] \\
\text { (FN)-FA-[FPrep }]\end{array}$ & 9 & $\begin{array}{l}\text { (FN)-FA-[FN] } \\
\text { (FN)-FA-[FPrep] } \\
\text { (FN)-FA-[FN] }\end{array}$ \\
\hline
\end{tabular}

Pola pertama hanya memiliki satu variasi pola, yaitu (FN)-FA. Variasi pola kalimat tersebut sudahdigunakan dan dikuasai anak usia $4-9$ tahun. Perkembangan variasi ini terlihat dari digunakannya predikat FA koordinasi. Koordinasi FA terbenuk dari penambahan konjungsi dan/sama di antara dua jenis kategori adjektiva. Akan tetapi, predikat FA koordinasi hanya digunakan anak usia 8 dan 9 tahun dengan frekuensi yang relatif sedikit, yaitu satu kalimat dari tuturana anak usia delapan dan sembilan tahun sehingga belum dikatakan sudah dikuasai. Berikut contoh kutipan kalimatnya.

(1) Squidweed itu besar. (4K110/A89/BFA)

(2) Anjingnya takut dan lucu. (8K330/D101/BFA)

FN FA koordinasi

Pola kedua berupa kalimat berpredikat FA dengan satu argumen dan satu keterangan tambahan. Pola kalimat ini memiliki dua variasi. Hadirnya keterangan tambahan menunjukkan perkembangan kalimat berpredikat FA. Variasi pertama, (FN)-FA-[FPrep]

telah digunakan dalam tuturan anak usia $5-8$ tahun dan dikuasai oleh anak usia $5-9$ tahun. Berbeda dengan variasi kedua (FN)-FA-[FN] telah digunakan dan dikuasai anak usia 6-9 tahun. Berikut kutipan kalimatnya.

(1) Jame apik-apik ndek pasar. (5K254/A132/BFA)

FN FA [FPrep]

(2) Kemarin kucinge adekku sakit. (6222K/B132/BFA) [FN] FN FA 
Keempat, perkembangan kalimat berpredikat FPrep. Berikut ini variasi kalimat dari kedua pola tersebut yang telah digunakan anak usia $4-9$ tahun.

Tabel 6. Variasi Kalimat Berpredkat FPrep

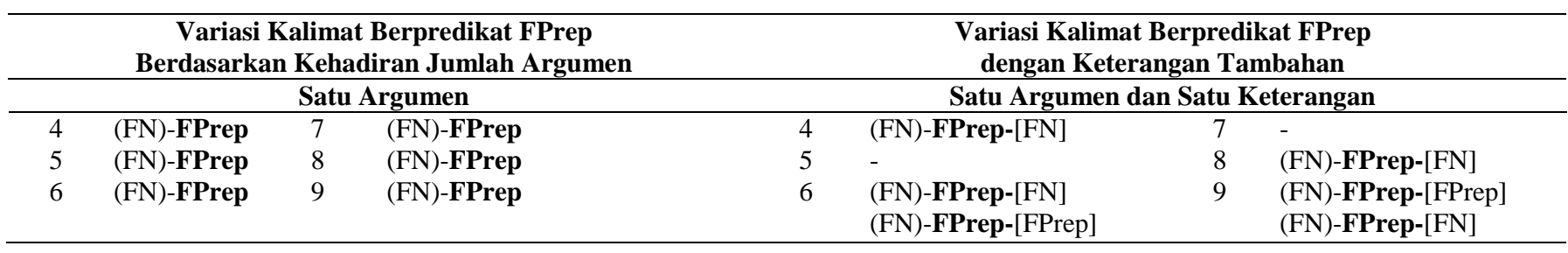

Kalimat berpredikat FPrep dengan satu argumen. Argumen yang mendampingi predikat merupakan argumen luar. Pola pertama ada stu variasi (FN)-FPrep. Variasi tersebut telah digunakan dan dikuasai anak usia 4—9 tahun. Berikut contoh kutipan kalimtanya.

(1) $\frac{\text { Kuenya Aldi kulkas. }}{\text { FN FPrep }}$ (4K167/A102/BFPrep)

Kalimat berpredikat dengan satu argumen dan satu keterangan tambahan. Ada dua variasi pada pola ini (FN)-FPrep[FN] yang sudah digunakan anak usia 4, 6, 7, 8, dan 9 tahun dan variasi (FN)-FPrep-[FPrep] sudah digunakan dalam tuturan 6, 8 , dan 9 tahun. Akan tetapi, variasi pertama sudah dikuasai anak usia $4-9$ tahun dan variasi kedua dikuasai anak $6-9$ tahun. Berikut ini contoh kutipan kalimatnya.

(1) Nanti aku ke rumahnya Afnan. (4K230/A186/BFPrep) [FN]FN FPrep

(2) Aku di sana dengan Mbak Wila. (6K54/B29/BFPrep)

Kelima, perkembangan kalimat berpredikat FNum. Berikut ini tabel variasi dan contoh kutipan kalimat berpredikat FNum yang digunakan anak usia 4-9 tahun. Perkembangan pola ini terlihat dari digunakannya FN berpenjelas pada argumen luar. Anak usia 4-9 tahun sudah menggunakan dan menguasai variasi pola (FN)-FNum, tetapi FN berpenjelas pada argumen luarnya hanya digunakan dalam tuturan anak usia delapan dan sembilan tahun dengan frekuensi relatif sedikit sehingga belum dapat dikatakan sudah dikuasai.

Tabel 7. Variasi Kalimat Berpredikat FNum

\begin{tabular}{ccccc}
\hline \multicolumn{5}{c}{ Variasi Kalimat Berpredikat FPrep Berdasarkan Kehadiran Jumlah Argumen } \\
\hline Usia & & Satu Argumen & Usia & Satu Argumen \\
\hline 4 & (FN)-FNum & 7 & (FN)-FNum \\
5 & (FN)-FNum & 8 & (FN)-FNum \\
6 & (FN)-FNum & 9 & (FN+Penjelas(yang+A))-FNum \\
& & & (FN)-FNum \\
& & & (FN+Penjelas(yang+A))-FNum \\
\hline
\end{tabular}

(1) $\frac{\text { Robotkuenam. }}{\text { FN } \text { FNum }}$ (4K247/A200/BFNum)

(2) Keong yang besarenam ribuan. $(8 \mathrm{~K} 498 / \mathrm{C} 33 / \mathrm{BFNum})$ FN berpenjelas (yang $+\mathrm{A}$ ) FNum

Berdasarkan kelima pola kalimat berpredikat, anak usia 4-9 tahun lebih banyak mengembangkan kalimatnya dengan menggunakan inti leksikal verba. Temuan ini memiliki kesamaan dengan penelitian Ghazali (1999) bahwa anak lebih banyak menggunakan inti leksikal verba daripada adjektiva. Banyaknya jumlah kalimat yang dikembangkan dengan inti leksikal verba berkaitan dengan karakteristik verba. Ada tiga karakteristik verba yang menyebabkan kalimat lebih mudah dikembangkan, yaitu (1) memiliki lebih banyak afiksasi daripada kategori frasa lain, (2) lebih mudah diikuti kategori frasa lain, seperti FN, FA, FPrep, atau FNum sebagai argumen dalam atau komplemen, dan (3) lebih mudah untuk menunjukkan aktivitas berpikir. Banyaknya variasi kalimat berpredikat FV juga dipengaruhi perkembangan kognitif anak usia 4-9 tahun. Peningkatan kemampuan berbahasa berbanding lurus dengan kemampuan kognitif. Perkembangan bahasa sebagai indikator dari adanya perkembangan kognitif (Hartanto, dkk., 2011; Kurniati, 2017). Anak usia 4-6 menurut klasifkasi Piaget termasuk dalam tahap praoperasional, sedangkan usia $7-9$ tahun dalam tahap operasional konkret.

Anak pada periode operasional konkret sudah mulai berkurang bahasanya yang bersifat egoisentris dan berubah lebih komunikatif. Menurut Simatwa (2010), periode operasional konkret merupakan periode peralihan bahasa dari yang bersifat egoisentris menuju bahasa yang sosialis atau memahami bahasa lawan bicaranya. Selain itu, anak dalam periode ini sudah dapat berpikir logis tentang objek dan peristiwa. Kategori kosakata yang dibutuhkan untuk menggambarkan suatu peristiwa dari 
aktivitas berpikir logis adalah frasa verba. Oleh karena itu, pola dan variasi kalimat berpredikat FV lebih banyak digunakan oleh anak usia 7-9 tahun. Karakteristik kalimat anak pada periode praoperasional ini berupa penggunaan kata-kata yang mewakili objek berdasarkan satu fitur, contohnya warna dan bentuk.

Menurut Clark (2004), kemampuan kognitif dasar anak-anak merupakan representasi konseptual dari hubungan objek dengan peristiwa yang pada akhirnya dapat digunakan anak-anak untuk memetakan kata-kata. Berdasarkan pendapat tersebut dapat diketahui bahwa anak pada periode praoperasional kalimatnya lebih banyak dikembangkan dengan frasa nomina. Pernyataan tersebut berbeda dengan hasil penelitian ini karena anak usia 4-6 tahun juga lebih banyak menggunakan kalimat berpredikat FV daripada FN. Hal ini dapat terjadi karena kalimat anak usia 4-6 tahun itu merupakan hasil dari proses imitasi atau meniru kalimat orang dewasa. Input kalimat diperoleh anak tersebut dari kalimat orang di sekitarnya yang mengggunakan kalimat berpredikat FV. Menurut Menyuk (1977), kalimat anak usia 3-7 tahun bukan diproduksi secara spontan dari kognitif anak tersebut, melainkan dari proses meniru dari kalimat orang yang lebih dewasa sehingga kalimat yang dihasilkan melebihi dari yang dikuasai. Anak-anak usia 4-6 tahun saat mengimitasi kalimat orang dewasa tidak secara murni, melainkan mereka mengasimilasi dan memilihnya sesuai dengan kemampuannya sendiri (Ahmad, dkk., 2016). Dalam penelitian Dardjowidjojo juga menjelaskan bahwa anak lebih sering menggunakan kalimat berpredikat FV. Dardjowidjojo (2000) menemukan bahwa struktur internal verba lebih banyak dikembangkan Echa karena verba lebih bersifat relasional sehingga dapat digunakan untuk mengungkapkan apa yang ingin diungkapkan.

Perkembangan kalimat dari segi c-select dapat dilihat dari jumlah argumen yang hadir, adanya konstituen tambahan yang hadir untuk mengikuti konstituen minimal, dan penggunaan unsur koordinatif. Penggunaan konstituen tambahan menunjukkan kekompleksan suatu kalimat. Pada anak usia yang lebih rendah ditandai oleh terbatasnya jumlah unsur keterangan yang hadir. Semakin tinggi usianya, semakin banyak unsur keterangan yang ditambahkan, baik dilihat dari jumlah ataupun bentuknya. Keterangan tambahan yang hadir dapat berupa keterangan waktu, cara, tempat, tujuan, dan alat. Keterangan tambahan yang hadir pada kalimat anak usia yang lebih rendah variasi lebih sedikit daripada keterangan yang dihasilkan anak usia lebih tinggi. Kalimat berpredikat dengan kehadiran argumen dan keterangan tambahan yang dihasilkan anak usia 5-9 tahun bisa mencapai dua macam keterangan sekaligus, sedangkan anak usia 4 tahun hanya menghadirkan satu keterangan. Kategori frasa yang telah digunakan dan dikuasai anak usia 4-9 tahun untuk menduduki keterangan adalah FN dan FPrep, sedangkan FA hanya digunakan dalam kalimat anak usia delapan tahun dalam jumlah relatif sedikit. Perkembangan kalimat yang lain terlihat dari adanya struktur koordinatif. Struktur koordinatif ditemukan pada FV sebagai predikat, FN sebagai argumen luar, argumen dalam, atau komplemen, dan FA sebagai predikat. Struktur koordinasi ini dibentuk dengan menambahkan konjungsi dan/sama di antara jenis kategori nomina, verba, atau adjektiva. Selain itu, dalam data juga ditemukan struktur koordinasi yang tidak hanya mengkoordinasikan dua nomina melainkan sampai tiga nomina. Perkembangan kalimat dari jumlah argumen yang hadir lebih bervariasi dan jumlahnya lebih banyak dihasilkan dari kalimat anak yang usianya lebih tinggi. Kalimat berpredikat FV dengan tiga argumen inti hanya digunakan dan dikuasai anak usia sembilan tahun, sedangkan anak usia 4-8 tahun belum menggunakan dan tidak menguasai.

Kategori frasa yang telah dikuasai dan digunakan anak usia 4-9 tahun untuk menduduki argumen luar dan argumen dalam adalah FN, FN koordinasi, dan FN berpenjelas. FN yang paling sering digunakan anak usia $4-9$ tahun untuk menduduki argumen luar berupa pronomina persona pertama tunggal (aku/saya), nama orang, atau nomina murni (benda-benda di sekitar mereka). Pronomina persona kedua sudah digunakan anak usia empat tahun, tetapi frekuensi hadirnya dalam argumen luar masih sedikit, sedangkan anak usia $8-9$ tahun sudah menguasai. Selain itu, pronomina persona pertama jamak juga sudah dikuasai anak usia $7-9$ tahun. Kategori frasa yang dapat menduduki komplemen lebih banyak daripada argumen dalam, yaitu FN, FN koordinasi, FN berpenjelas, FA, FV, FNum, dan FPrep. Argumen dalam dan komplemen hanya hadir pada kalimat berpredikat FV. FNum yang paling banyak digunakan dan sudah dikuasai, baik sebagai predikat, komplemen, atau penjelas dari nomina adalah numeralia tentu (angka atau jumlah).

\section{SIMPULAN}

Pertama, perkembangan s-select kalimat anak usia 4-9 tahun. Perkembangan s-select dapat diketahui dari jumlah pola $s$-select kalimat yang digunakan dan dikuasai, jumlah peran theta yang hadir pada kalimat, dan variasi peran theta yang digunakan. Ada 4 polas-select kalimat, yaitu (1) kalimat berpredikat dengan satu peran theta, (2) kalimat berpredikat dengan dua peran theta, (3) kalimat berpredikat dengan tiga peran theta, dan (4) kalimat berpredikat dengan peran theta wajib dan opsional. Anak usia 4-8 tahun hanya menggunakan dan menguasai sebelas peran theta, yaitu peran agen, tema, pelaksana, penderita, tujuan, persepsi, waktu, lokasi, sumber, instrumen, dan cara. Anak usia sembilan tahun sudah dapat menggunakan dan menguasai 13 peran theta yang telah dijelaskan oleh Cowper dan Haegeman.

Ada enam peran theta opsional untuk mengisi keterangan tambahan, yaitu peran theta lokasi, sumber, cara, instrumen, tujuan, dan waktu. Peran theta yang menduduki argumen luar dapat berupa agen, tema, dan pelaksana, sedangkan pada argumen dalam berupa peran penderita, tema, dan persepsi. Ada enam peran theta yang dapat menduduki komplemen, yaitu penderita, tema, persepsi, tujuan, penerima, dan benefaktif. 
Kedua, perkembangan -select kalimat anak usia 4-9 tahun. Anak mengembangkan kalimat berdasarkan inti leksikal pada predikat, yaitu verba, adjektiva, nomina, numeralia, dan preposisi. Ada 4 pola kalimat berpredikat FV, yaitu kalimat berpredikat FV dengan satu argumen, dua argumen, tiga argumen, dan kalimat berpredikat FV dengan argumen dan keterangan tambahan. Kalimat berpredikat FN, FA, FNum, dan FPrep masing-masing memiliki dua pola, yaitu kalimat berpredikat FN/FA/FNum/FPrep dengan satu argumen dan kalimat berpredikat FN/FA/FNum/FPrep dengan satu argumen dan keterangan tambahan. Kategori frasa yang menduduki argumen luar dan dalam berupa FN, FN koordinasi, dan FN berpenjelas. Kata benda yang paling banyak dikuasai anak usia 4-9 tahun untuk menduduki argumen luar berupa pronomina persona pertama tunggal, nama orang, dan nomina murni. Kategori frasa yang dapat menduduki komplemen berupa FN, FN koordinasi, FN berpenjelas, FV, FA, FPrep, dan FNum. Kategori frasa yang menduduki keterangan tambahan kalimat berpredikat FV, yaitu FN, FA, dan FPrep, sedangkan pada kalimat FN, FA, FPrep, dan FNum dapat diisi dengan FN dan FPrep.

\section{DAFTAR RUJUKAN}

Ahmad, S., Hussain, A., Batool, A., Sittar, K., \& Malik, M. (2016). Play and Cognitive Development: Formal Operational Perspective of Piaget's Theory. Journal of Education and Practice, 7(28), 72-79.

Al-Shujairi, Y. B. J., Muhammed, A., \& Almahammed, Y. S. O. (2015). Transitivity and Intransitivity in English and Arabic: A Comparative Study. International Journal of Linguistics, 7(6), 38-52. https://doi.org/10.5296/ijl.v7i6.8744

Arsanti, M. (2014). Pemerolehan Bahasa pada Anak: Kajian Psikolinguistik. Jurnal PBSI, 3(2), $24-47$.

Branigan, H. P., Pickering, M. J., \& Tanaka, M. (2008). Contributions of Animacy to Grammatical Function Aassignment and Word Order during Production. Lingua Journal, 118(2), 172-189. https://doi.org/10.1016/j.lingua.2007.02.003

Chomsky, C. (1969). The Acquisition of Syntax in Children from 5 to 10. London: The M.I.T. Press.

Clark, E. V. (2004). Language and Conceptual Development Series: How Language Acquisition Builds on Cognitive Development. Trends in Cognitive Sciences Journal, 8(10), 472-478. https://doi.org/10.1016/j.tics.2004.08.012

Cowper, E. A. (1992). A Concise Introductionto Syntactic Theory: The Government-Binding Approach. Chicago: The University of Chicago Press.

Dardjowidjojo, S. (2000). Echa: Kisah Pemerolehan Bahasa Anak Indonesia. Jakarta: PT Grasindo.

Dong, G., \& Ren, H. (2013). The Role of Age in Second Language Acquisition:A Psychological Perspective. British Journal of English Linguistics, 1(1), 1-6.

Ghazali, S. (1999). Kerumitan Kalimat Bahasa Indonesia Siswa Sekolah Dasar (Disertasi tidak diterbitkan). Pascasarjana Universitas Negeri Malang, Malang.

Haegeman, L. (1977). Introduction to Goverenment and Binding Theory. Oxford: Blackwell.

Hartanto, F., Selina, H., Zuhriah, \& Fitra, S. (2011). Pengaruh Perkembangan Bahasa Terhadap Perkembangan Kognitif Anak Usia 1-3 Tahun. Jurnal Sari Pediatri, 12(6), 386-389.

Hutauruk, B. S. (2015). Children First Language Acquisition at Age 1-3 Years Old in Balata. Journal Of Humanities And Social Science, 20(8), 51-57. https://doi.org/10.9790/0837-20855157

Koymen, B., Lieven, E., \& Brandt, S. (2015). Syntactic and Semantic Coordination in Finite Complement-Clause Constructions: A Diary-Based Case Study. Journal of Child Language, 42(4), 1-21. https://doi.org/10.1017/S0305000914000853

Kurniati, E. (2017). Perkembangan Bahasa pada Anak dalam Psikologi serta Implikasinya dalam Pembelajaran. Jurnal Ilmiah Universitas Batanghari Jambi, 17(3), 47-56.

Maisarah, Kadhim, K. A., \& Veesar, Z. A. (2016). Semantic Analysis of Theta Roles of Verbs in The Mah Meri Language. English Review: Journal of English Education, 5(1), 49-70.

Marantz, A. (2013). Verbal Argument Structure: Events and Participants. Lingua Journal, 130(2013), 152-168. https://doi.org/10.1016/j.lingua.2012.10.012

Marlina, R. (2012). The Analysis of Thematic Role in Narrative Texts of Senior High School Textbooks. English Review: Journal of English Education, 1(1), 80-88.

Menyuk, P. (1977). Language and Maturation. Cambridge: MIT Press.

Plante, E., Almryde, K., Patterson, D. K., Vance, C. J., \& Asbjornsen, A. E. (2015). Language Lateralization Shifts with Learning by Adults. Laterality Journal, 20(3), 306-325. https://doi.org/10.1080/1357650X.2014.963597

Rakhlin, N., Kornilov, S. A., Reich, J., Babyonyshev, M., Koposov, R. A., \& Grigorenko, E. L. (2011). The Relationship between Syntactic Development and Theory of Mind: Evidence from a Small-Population Study of a Developmental Language Disorder. Journal of Neurolinguistics, 24(4), 476-496.

Saffran, J. R., Senghas, A., \& Trueswell, J. C. (2001). The Acquisition of Language by Children. PNAS Journal, 98(23), $12874-12875$.

Samsuri. (1985). Tata Kalimat Bahasa Indonesia. Jakarta: Sastra Hudaya.

Schwantes, F. M. (1991). Children's Use of Semantic and Syntactic Information for Word Recognition and Determination of Sentence Meaningfulness. Journal of Reading Behavior, 23(3), 335-350.

Sebayang, S. K. H. (2018). Analisis Pemerolehan Bahasa Pertama (Bahasa Melayu) pada Anak Usia Tiga Tahun. Jurnal Pena Indonesia, 4(1), 105-114. 
Sells, P. (1985). Lectures On Contemporary Syntactic Theories: An Introduction to Government-Binding Theory Generalized Phrase Structure Grammar and Lexical Functional Grammar. Stanford: Center for The Study Language and Information.

Simatwa, E. M. W. (2010). Piaget's Theory of Intellectual Development and Its Implication for Instructional Management at Presecondary School Level. Academic Journals: Educational Research and Reviews, 5(7), 366-371.

Taylor, I., \& Taylor, M. M. (1990). Psycholinguistics: Learning and UsingLanguage. New York: Prentice-Hall International, Inc.

Veesar, Z. A., Kadhim, K. A., \& Bagudu, R. S. (2015). The Most Prominent Theta Roles in the Sindhi Language: The Hierarchy. International Journal of Foreign Language Teaching \& Research, 3(12), 11-24. 